\title{
Dyslipidemia rather than Type 2 Diabetes Mellitus or Chronic Periodontitis Affects the Systemic Expression of Pro- and Anti-Inflammatory Genes
}

\author{
Rafael Nepomuceno, ${ }^{1}$ Bárbara Scoralick Villela, ${ }^{1}$ Sâmia Cruz Tfaile Corbi, ${ }^{1}$ \\ Alliny De Souza Bastos, ${ }^{2}$ Raquel Alves Dos Santos, ${ }^{3}$ Catarina Satie Takahashi, ${ }^{4,5}$ \\ Silvana Regina Perez Orrico, ${ }^{2}$ and Raquel Mantuaneli Scarel-Caminaga ${ }^{1}$ \\ ${ }^{1}$ Department of Morphology, School of Dentistry at Araraquara, São Paulo State University (UNESP), \\ 14801-903 Araraquara, SP, Brazil \\ ${ }^{2}$ Department of Diagnosis and Surgery, School of Dentistry at Araraquara, São Paulo State University (UNESP), \\ 14801-903 Araraquara, SP, Brazil \\ ${ }^{3}$ Postgraduate Program in Sciences of the University of Franca, 14404-600 Franca, SP, Brazil \\ ${ }^{4}$ Department of Genetics, Faculty of Medicine of Ribeirão Preto, University of São Paulo (USP), 14040-900 Ribeirão Preto, SP, Brazil \\ ${ }^{5}$ Department of Biology, Faculty of Philosophy, Sciences and Letters at Ribeirão Preto, University of São Paulo (USP), \\ 14040-900 Ribeirão Preto, SP, Brazil
}

Correspondence should be addressed to Rafael Nepomuceno; rafaelnepomuceno@gmail.com and Raquel Mantuaneli Scarel-Caminaga; raquel@foar.unesp.br

Received 8 September 2016; Accepted 26 January 2017; Published 20 February 2017

Academic Editor: Anshu Agrawal

Copyright (C) 2017 Rafael Nepomuceno et al. This is an open access article distributed under the Creative Commons Attribution License, which permits unrestricted use, distribution, and reproduction in any medium, provided the original work is properly cited.

\begin{abstract}
A high percentage of type 2 diabetes mellitus (T2D) patients are also affected by dyslipidemia and chronic periodontitis (CP), but no studies have determined the gene expression in patients that are simultaneously affected by all three diseases. We investigated the systemic expression of immune-related genes in T2D, dyslipidemia, and CP patients. One hundred and fifty patients were separated into five groups containing 30 individuals each: (G1) poorly controlled T2D with dyslipidemia and CP; (G2) well-controlled T2D with dyslipidemia and CP; (G3) normoglycemic individuals with dyslipidemia and CP; (G4) healthy individuals with CP; (G5) systemic and periodontally healthy individuals. Blood analyses of lipid and glycemic profiles were carried out. The expression of genes, including IL10, JAK1, STAT3, SOCS3, IP10, ICAM1, IFNA, IFNG, STAT1, and IRF1, was investigated by RT-qPCR. Patients with dyslipidemia demonstrated statistically higher expression of the IL10 and IFNA genes, while IFNG, IP10, IRF1, JAK1, and STAT3 were lower in comparison with nondyslipidemic patients. Anti-inflammatory genes, such as IL10, positively correlated with parameters of glucose, lipid, and periodontal profiles, while proinflammatory genes, such as IFNG, were negatively correlated with these parameters. We conclude that dyslipidemia appears to be the primary disease that is associated with gene expression of immune-related genes, while parameters of T2D and CP were correlated with the expression of these important immune genes.
\end{abstract}

\section{Introduction}

Type 2 diabetes mellitus (T2D) encompasses individuals who have insulin resistance and who usually have relative (rather than absolute) insulin deficiency and decreased $\beta$ cell function $[1,2]$. T2D is characterized not only by changes in carbohydrate metabolism, but also by changes in the metabolism of lipids, which is defined in the literature as diabetic dyslipidemia. Therefore, it is important to emphasize the fact that T2D may exist concurrently and/or synergistically with other systemic diseases, such as dyslipidemia, since there is a direct relationship between indices of glycemic control and plasma lipid elevation [3, 4]. Moreover, it is estimated that patients with diabetes have a two- to fourfold higher risk of ischemic disease. Dyslipidemia is a major risk factor for macrovascular complications in T2D patients [5]. 
In patients with diabetes, alteration in the distribution of lipids increases the risk of atherosclerosis [6]. Dyslipidemia in association with diabetes mellitus is the major cause of morbidity and mortality due to the high rate of severe cardiovascular diseases [3].

Dyslipidemia is a very common metabolic abnormality, which is characterized by a spectrum of quantitative and qualitative changes in serum lipids and lipoproteins [7]. The main characteristics of dyslipidemia include high total cholesterol (TC), high triglycerides (TG), elevated low-density lipoprotein (LDL), and decreased high-density lipoprotein (HDL) [8]. The cause of dyslipidemia may be genetic, environmental, or both.

Chronic periodontitis (CP) is an infectious disease that affects dental supporting tissues (attachment and bone loss) and is caused predominantly by Gram-negative anaerobic bacteria $[9,10]$. CP induces local and systemic elevation of proinflammatory cytokines, and these molecules contribute to soft and hard periodontal tissue destruction and loss of dental elements, in addition to the prevalence and severity of systemic diseases, such as diabetes and dyslipidemia [11-15]. Reports have suggested that CP and dyslipidemia/diabetes may be involved in a two-way relationship [13-15]. CP has been recognized as the sixth most common complication associated with T2D [16]. Also, T2D patients demonstrated a greater extent and severity of CP compared to normoglycemic individuals [17-19]. Moreover, in recent years, several papers have investigated the relationships between periodontitis and lipid parameters. Dyslipidemia increases the risk for $\mathrm{CP}$, and periodontal inflammation negatively affects serum lipid control $[13,20]$.

The IL10, IL10RA, IL10RB, JAK1, STAT3, SOCS3, IP10, ICAM1, IFNA, IFNARA, IFNAR2, IFNG, IFNGR1, IFNGR2, $S T A T 1$, and IRF1 genes are important molecules associated with the host immunoinflammatory response. There are limited studies on the association between these genes and the multifactorial diseases T2D, dyslipidemia, and chronic periodontitis. Moreover, there are no studies investigating the expression of these genes in subjects concomitantly affected by these three pathologies. In view of the literature, and because it has been increasingly common to find T2D patients that are also affected by a combination of dyslipidemia and chronic periodontitis, our hypothesis was that glycemic control, lipid profile, and periodontal status can alter the systemic expression of pro- and anti-inflammatory genes. Therefore, the aim of the present study was to evaluate the expression of important genes of the IL10 and interferonalpha and -gamma pathways in poorly or well-controlled T2D patients and in normoglycemic individuals, both conditions associated with dyslipidemia and chronic periodontitis. In addition, correlation analyses were made in order to determine the influence of the glycemic/lipid levels and periodontal parameters on the expression of these important genes.

\section{Materials and Methods}

2.1. Selection Criteria. The study was approved by the Ethics in Human Research Committee of the Araraquara School of Dentistry (UNESP, Univ. Estadual Paulista, Araraquara,
Brazil; Protocol number 50/06) and was conducted according to the ethical principles of the Declaration of Helsinki between 2009 and 2011. All volunteers were informed about the aims and methods of this study, and they provided their written consent to participate.

We evaluated 1788 patients, age ranging from 35 to 60 years, similar socioeconomic level and with at least 15 natural teeth. Patients were excluded according to the criteria described in Bastos et al. (2012) [21] and Corbi et al. (2014) [22].

2.2. Clinical Record and Physical Evaluation. The individuals answered a structured questionnaire about demographic characteristics, personal and family medical history, and use of medications. A trained examiner collected information regarding time since the diagnosis of diabetes, use of hypoglycemic medication, and presence of diabetes-associated complications. Subjects completed a physical examination including measurement of waist and hip circumference (centimeters), height (meters), weight (kilograms), and body mass index (BMI).

\subsection{Laboratory Measurements of Metabolic Control and} Lipoprotein Profile. The same laboratory performed all analyses, and blood samples were collected after a $12 \mathrm{~h}$ overnight fast for the evaluation of fasting plasma glucose $(\mathrm{mg} / \mathrm{dL})$ by a modified Bondar and Mead method [23]. Glycated hemoglobin (HbAlc) was measured by enzymatic immunoturbidimetry, insulin levels were measured by the chemiluminescence method (U/L), and lipid profile (TC, TG, and HDL) was measured by enzymatic methods. LDL was determined by the Friedewald formula.

Patients were considered as nondiabetics (normoglycemic individuals) if they presented fasting glucose levels $<100 \mathrm{mg} / \mathrm{dL}$ and HbAlc $<6.5 \%$. T2D patients that were diagnosed by an endocrinologist and who monitored their glycemic control by evaluation of $\mathrm{HbAlc}$ were divided into poorly controlled patients $(\mathrm{HbAlc} \geq 8.5 \%, 64 \mathrm{mmol} / \mathrm{mol}$ ) or well-controlled patients $(\mathrm{HbAcl}<7.0 \%)$ [24]. Insulin resistance was also evaluated for insulin levels by the chemiluminescence method $(\mu \mathrm{U} / \mathrm{mL})$ for calculation of the homeostasis model assessment (HOMA) of the insulin resistance index [25].

To avoid the inclusion of individuals with transitory dyslipidemia, the cutoff points used were the highest values according to the National Cholesterol Educational Program Adult Treatment III (total cholesterol $\geq 240 \mathrm{mg} / \mathrm{dL}, \mathrm{LDL} \geq$ $160 \mathrm{mg} / \mathrm{dL}, \mathrm{HDL} \leq 40 \mathrm{mg} / \mathrm{dL}$, and TG $\geq 200 \mathrm{mg} / \mathrm{dL}$ ). Patients were considered affected by dyslipidemia when they presented abnormal levels of at least one of the abovementioned parameters [26].

2.4. Periodontal Clinical Examination. All patients were subjected to a periodontal clinical examination performed as described in Corbi et al. (2014) [22]. Chronic periodontitis, as defined by the American Academy of Periodontology [27], includes local signs of inflammation and tissue destruction (presence of deep periodontal pockets $\geq 6 \mathrm{~mm}$ ) and loss of 
TABLE 1: Periodontal parameters of the sample (mean \pm SD).

\begin{tabular}{|c|c|c|c|c|c|}
\hline Parameters & $\begin{array}{l}\text { Group } 1 \\
n=30\end{array}$ & $\begin{array}{c}\text { Group } 2 \\
n=30\end{array}$ & $\begin{array}{c}\text { Group } 3 \\
n=30\end{array}$ & $\begin{array}{c}\text { Group } 4 \\
n=30\end{array}$ & $\begin{array}{c}\text { Group } 5 \\
n=30\end{array}$ \\
\hline Number of teeth & $22.3( \pm 4.2)^{\mathrm{a}}$ & $21.6( \pm 4.5)^{\mathrm{a}}$ & $23.2( \pm 3.8)^{\mathrm{a}}$ & $24.3( \pm 3.1)^{\mathrm{a}}$ & $27.1( \pm 1.8)$ \\
\hline $\begin{array}{l}\text { Percentage of sites with } \\
\text { visible plaque }\end{array}$ & $76.5( \pm 17.4)^{\mathrm{a}, \mathrm{b}}$ & $69.8( \pm 13.0)^{\mathrm{a}}$ & $70.1( \pm 15.7)^{\mathrm{a}}$ & $60.8( \pm 17.4)^{\mathrm{a}}$ & $14.8( \pm 6.2)$ \\
\hline $\begin{array}{l}\text { Percentage of sites with } \\
\text { marginal bleeding }\end{array}$ & $60.9( \pm 15.2)^{\mathrm{a}, \mathrm{b}, \mathrm{c}}$ & $46.9( \pm 15.9)^{\mathrm{a}}$ & $40.4( \pm 14.8)^{\mathrm{a}}$ & $41.3( \pm 12.9)^{\mathrm{a}}$ & $8.7( \pm 4.8)$ \\
\hline $\begin{array}{l}\text { Percentage of sites with } \\
\text { bleeding on probing }\end{array}$ & $69.3( \pm 12.8)^{\mathrm{a}, \mathrm{b}, \mathrm{c}, \mathrm{d}}$ & $53.9( \pm 13.8)^{\mathrm{a}}$ & $53.0( \pm 13.7)^{\mathrm{a}}$ & $51.4( \pm 13.2)^{\mathrm{a}}$ & $12.7( \pm 5.6)$ \\
\hline $\begin{array}{l}\text { Mean of the probing depth } \\
(\mathrm{mm})\end{array}$ & $4.1( \pm 0.5)^{\mathrm{a}, \mathrm{b}, \mathrm{c}, \mathrm{d}}$ & $3.7( \pm 0.6)^{\mathrm{a}}$ & $3.4( \pm 0.5)^{\mathrm{a}}$ & $3.7( \pm 0.4)^{\mathrm{a}}$ & $2.1( \pm 0.2)$ \\
\hline $\begin{array}{l}\text { Percentage of sites with } \\
\text { probing depth } \leq 3 \mathrm{~mm}\end{array}$ & $43.3( \pm 14.8)^{\mathrm{a}, \mathrm{c}, \mathrm{d}}$ & $57.0( \pm 15.0)^{\mathrm{a}}$ & $61.9( \pm 14.0)^{\mathrm{a}}$ & $53.3( \pm 12.5)^{\mathrm{a}}$ & $98.8( \pm 1.5)$ \\
\hline $\begin{array}{l}\text { Percentage of sites with } \\
\text { probing depth }=4-5 \mathrm{~mm}\end{array}$ & $31.9( \pm 11.6)^{\mathrm{a}, \mathrm{b}}$ & $31.0( \pm 11.0)^{\mathrm{a}, \mathrm{b}}$ & $31.0( \pm 10.6)^{\mathrm{a}, \mathrm{b}}$ & $41.0( \pm 10.0)^{\mathrm{a}}$ & $1.2( \pm 1.5)$ \\
\hline $\begin{array}{l}\text { Percentage of sites with } \\
\text { probing depth } \geq 6 \mathrm{~mm}\end{array}$ & $24.8( \pm 15.9)^{\mathrm{a}, \mathrm{b}, \mathrm{c}}$ & $12.0( \pm 10.8)^{\mathrm{a}}$ & $7.0( \pm 10.6)^{\mathrm{a}}$ & $5.7( \pm 5.9)^{\mathrm{a}}$ & $0.0( \pm 0.0)$ \\
\hline $\begin{array}{l}\text { Mean of the attachment } \\
\text { loss }(\mathrm{mm})\end{array}$ & $4.4( \pm 0.7)^{\mathrm{a}, \mathrm{b}, \mathrm{c}, \mathrm{d}}$ & $3.9( \pm 0.7)^{\mathrm{a}}$ & $3.6( \pm 0.5)^{\mathrm{a}}$ & $3.8( \pm 0.4)^{\mathrm{a}}$ & $2.2( \pm 0.2)$ \\
\hline $\begin{array}{l}\text { Percentage of sites with } \\
\text { attachment loss } \leq 2 \mathrm{~mm}\end{array}$ & $13.1( \pm 8.8)^{\mathrm{a}}$ & $16.5( \pm 15.1)^{\mathrm{a}}$ & $24.8( \pm 16.2)^{\mathrm{a}, \mathrm{b}}$ & $10.3( \pm 10.0)^{\mathrm{a}}$ & $64.5( \pm 13.9)$ \\
\hline $\begin{array}{l}\text { Percentage of sites with } \\
\text { attachment loss }=3-4 \mathrm{~mm}\end{array}$ & $39.8( \pm 15.3)^{\mathrm{b}, \mathrm{c}}$ & $48.8( \pm 14.2)^{\mathrm{a}, \mathrm{b}}$ & $51.6( \pm 10.7)^{\mathrm{a}}$ & $61.3( \pm 10.0)^{\mathrm{a}, \mathrm{c}}$ & $35.5( \pm 13.9)$ \\
\hline $\begin{array}{l}\text { Percentage of sites with } \\
\text { attachment loss } \geq 5 \mathrm{~mm}\end{array}$ & $47.1( \pm 16.2)^{\mathrm{a}, \mathrm{b}, \mathrm{c}, \mathrm{d}}$ & $34.7( \pm 17.6)^{\mathrm{a}}$ & $23.8( \pm 14.0)^{\mathrm{a}}$ & $28.4( \pm 10.5)^{\mathrm{a}}$ & $0.0( \pm 0.0)$ \\
\hline $\begin{array}{l}\text { Number of sites with } \\
\text { suppuration }\end{array}$ & $6.8( \pm 7.0)^{\mathrm{a}, \mathrm{b}, \mathrm{c}, \mathrm{d}}$ & $4.0( \pm 3.3)^{\mathrm{a}}$ & $2.0( \pm 3.0)$ & $2.0( \pm 3.7)$ & $0.0( \pm 0.0)$ \\
\hline
\end{tabular}

${ }^{\mathrm{a}}$ Significant $P$ value in relation to group $5 ;{ }^{\mathrm{b}}$ significant $P$ value in relation to group $4{ }^{\mathrm{c}}$ significant $P$ value in relation to group 3 ; ${ }^{\mathrm{d}}$ significant $P$ value in relation to group 2. Comparisons between all groups for nonnormally distributed variables were performed by the Kruskal-Wallis test, and Dunn test was used to correct for multiple comparisons. For normally distributed variables, one-way analysis of variance (ANOVA) test with Holm-Sidak multiple comparison test was used.

the connective tissue attachment of gingiva to teeth (clinical attachment loss $\geq 4 \mathrm{~mm}$ ) in at least four nonadjacent teeth. Severe chronic periodontitis was defined as the presence of deep periodontal pockets $\geq 6 \mathrm{~mm}$ with clinical attachment loss of $\geq 5 \mathrm{~mm}$ and bleeding on probing in at least eight sites distributed in different quadrants of the dentition (Table 1) [28].

2.5. Study Population. After all the examinations described above, 150 patients were selected and divided into five groups (G) containing 30 individuals each based upon diabetic and dyslipidemic status: (G1) poorly controlled diabetics with dyslipidemia and chronic periodontitis; (G2) well-controlled diabetics with dyslipidemia and chronic periodontitis; (G3) normoglycemic individuals with dyslipidemia and chronic periodontitis; (G4) systemically healthy individuals with chronic periodontitis; and (G5) systemically healthy individuals without chronic periodontitis.

Because the patients enrolled here were the same as those investigated in previous studies of our research group, detailed information regarding recruiting, clinical inclusion criteria, and power analysis can be found in Bastos et al. (2012) [21] and Corbi et al. (2014) [22].
2.6. Reverse Transcriptase-Real-Time Quantitative PCR (RT$q P C R)$. Peripheral venous blood was collected from each subject and immediately centrifuged on a Ficoll-Paque PLUS (GE Healthcare Life Sciences, Oslo, Norway) density gradient, followed by consecutive washings with saline ( $\mathrm{NaCl} 0.9 \%)$, to isolate peripheral blood mononuclear cells (PBMCs). Total RNA samples were extracted using TRIzol reagent (Invitrogen, Rockville, MD, USA) according to the manufacturer's instructions. Samples containing total RNA were purified using the RNeasy Protection Mini Kit (Qiagen, Hilden, Germany). RNA was quantified using a NanoVue Spectrophotometer (GE Healthcare Life Sciences, Oslo, Norway), and its integrity was assessed by $1 \%$ agarose gel electrophoresis. Absorbances $(\lambda=260 / 280$ and 260/230) were measured, and samples with ratios lower than 1.8 and higher than 2.2 were discarded. cDNA was synthesized using oligodT primers and the SuperScript III First-Strand Synthesis Super Mix kit according to the manufacturer's instructions (Invitrogen). Real-time quantification of target mRNA was performed using SYBR Green (Applied Biosystems, Foster City, CA, USA) according to the manufacturer's instructions. Briefly, each amplification was performed in a total volume of $25 \mu \mathrm{L}$, containing $12.5 \mu \mathrm{L}$ SYBR Green Universal PCR 
TABLE 2: Characteristics of the sample: demographic, physical, biochemical, and diabetic data (mean \pm SD).

\begin{tabular}{|c|c|c|c|c|c|}
\hline & $\begin{array}{l}\text { Group } 1 \\
n=30\end{array}$ & $\begin{array}{c}\text { Group } 2 \\
n=30\end{array}$ & $\begin{array}{c}\text { Group } 3 \\
n=30\end{array}$ & $\begin{array}{c}\text { Group } 4 \\
n=30\end{array}$ & $\begin{array}{c}\text { Group } 5 \\
n=30\end{array}$ \\
\hline Gender (F/M) & $18 / 12$ & $20 / 10$ & $17 / 13$ & 19/11 & $18 / 12$ \\
\hline Age (mean SD) & $48.0( \pm 7.6)^{\mathrm{a}}$ & $50.3( \pm 6.7)^{\mathrm{a}}$ & $49.0( \pm 7.5)^{\mathrm{a}}$ & $45.9( \pm 5.9)^{\mathrm{a}}$ & $39.3( \pm 3.6)$ \\
\hline $\mathrm{BMI}\left(\mathrm{m} / \mathrm{Kg}^{2}\right)$ & $30.5( \pm 5.2)^{\mathrm{a}}$ & $31.4( \pm 4.1)^{\mathrm{a}, \mathrm{b}}$ & $28.4( \pm 3.8)$ & $27.3( \pm 6.4)$ & $24.5( \pm 3.5)$ \\
\hline Waist-to-hip ratio $(\mathrm{cm})$ & $1.0( \pm 0.1)^{\mathrm{a}, \mathrm{b}}$ & $1.0( \pm 0.1)^{\mathrm{a}, \mathrm{b}}$ & $0.9( \pm 0.1)^{\mathrm{a}}$ & $0.9( \pm 0.1)^{\mathrm{a}}$ & $0.8( \pm 0.07)$ \\
\hline $\begin{array}{l}\text { Abdominal circumference } \\
(\mathrm{cm})\end{array}$ & $104.3( \pm 14.6)^{\mathrm{a}}$ & $109.3( \pm 10.8)^{\mathrm{a}, \mathrm{b}, \mathrm{c}}$ & $98.1( \pm 9.9)$ & $98.2( \pm 16.9)$ & $87.5( \pm 10.6)$ \\
\hline Fasting glucose (mg/dl) & $226.6( \pm 74.2)^{\mathrm{a}, \mathrm{b}, \mathrm{c}, \mathrm{d}}$ & $137.5( \pm 41.4)^{\mathrm{a}, \mathrm{b}, \mathrm{c}}$ & $90.0( \pm 6.4)$ & $90.8( \pm 7.3)$ & $85.9( \pm 6.5)$ \\
\hline $\mathrm{HbA}_{1 \mathrm{c}}(\%)$ & $10.4( \pm 1.9)^{\mathrm{a}, \mathrm{b}, \mathrm{c}, \mathrm{d}}$ & $6.6( \pm 0.9)^{\mathrm{a}, \mathrm{b}, \mathrm{c}}$ & $5.4( \pm 0.6)$ & $5.1( \pm 0.6)$ & $5.4( \pm 0.21)$ \\
\hline Insulin (U/L) & $19.7( \pm 20.9)^{\mathrm{a}}$ & $21.1( \pm 21.5)^{\mathrm{a}, \mathrm{b}}$ & $12.6( \pm 8.5)$ & $11.1( \pm 12.7)$ & $7.1( \pm 4.3)$ \\
\hline HOMA & $12.7( \pm 15.9)^{\mathrm{a}, \mathrm{b}, \mathrm{c}}$ & $6.8( \pm 5.2)^{\mathrm{a}, \mathrm{b}, \mathrm{c}}$ & $2.6( \pm 1.8)$ & $2.9( \pm 3.5)$ & $1.6( \pm 1.0)$ \\
\hline Total cholesterol (mg/dl) & $242.7( \pm 37.8)^{\mathrm{a}, \mathrm{b}}$ & $243.4( \pm 42.9)^{\mathrm{a}, \mathrm{b}}$ & $246.1( \pm 42.3)^{\mathrm{a}, \mathrm{b}}$ & $171.6( \pm 18.5)$ & $180.3( \pm 21.5)$ \\
\hline HDL cholesterol (mg/dl) & $44.8( \pm 9.5)$ & $46.1( \pm 10.5)$ & $50.7( \pm 11.1)$ & $48.4( \pm 12.6)$ & $49.3( \pm 10.1)$ \\
\hline LDL cholesterol (mg/dl) & $153.4( \pm 37.0)^{\mathrm{a}, \mathrm{b}}$ & $147.3( \pm 44.3)^{\mathrm{a}, \mathrm{b}}$ & $156.4( \pm 44.1)^{\mathrm{a}, \mathrm{b}}$ & $103.8( \pm 17.4)$ & $113.5( \pm 18.1)$ \\
\hline Triglycerides (mg/dl) & $216.9( \pm 94.6)^{\mathrm{a}, \mathrm{b}}$ & $249.8( \pm 104.1)^{\mathrm{a}, \mathrm{b}}$ & $194.1( \pm 80.6)^{\mathrm{a}, \mathrm{b}}$ & $93.9( \pm 35.9)$ & $87.4( \pm 27.6)$ \\
\hline
\end{tabular}

${ }^{\mathrm{a}}$ Significant $P$ value in relation to group 5; ${ }^{\mathrm{b}}$ significant $P$ value in relation to group $4{ }^{\mathrm{c}}{ }^{\mathrm{c}}$ significant $P$ value in relation to group 3 ; ${ }^{\mathrm{d}}$ significant $P$ value in relation to group 2. Comparisons between all groups for nonnormally distributed variables were performed by the Kruskal-Wallis test, and Dunn test was used to correct for multiple comparisons. For normally distributed variables, one-way analysis of variance (ANOVA) test with Holm-Sidak multiple comparison test was used.

Master Mix 2x (Applied Biosystems), $500 \mathrm{nM}$ each forward and reverse PCR primers, and $3 \mathrm{ng}$ of cDNA. Detailed information regarding sequences of primers and real-time PCR cycling parameters are described in previous studies [29, 30] and in Supplemental Table 1 (in Supplementary Material available online at https://doi.org/10.1155/2017/1491405). The investigated target genes were IL10, IL10RA, IL10RB, JAK1, STAT3, SOCS3, IP10, ICAM1, IFNA, IFNARA, IFNAR2, IFNG, IFNGR1, IFNGR2, STAT1, and IRF1. The specificity of the amplified PCR products was confirmed by dissociation curve analysis. All reactions were performed in duplicate, and the examiner was blinded regarding which group each sample belonged to. Relative quantitation of mRNA was carried out after normalization of the gene expression to the GAPDH endogenous control gene. To calculate gene expression, Expression Suite Software (Applied Biosystems) was used, which employs the comparative $C \tau(\Delta C \tau)$ method for multiple data analysis.

2.7. Statistical Analysis. The distribution of the data was evaluated by D'Agostino-Pearson omnibus normality test. Comparisons between all groups for nonnormally distributed variables (e.g., $2^{-\Delta \mathrm{C} \tau}$ values of gene expression) were performed by the Kruskal-Wallis test, and Dunn test was used to correct for multiple comparisons. For normally distributed variables, one-way analysis of variance (ANOVA) test with Holm-Sidak multiple comparison test was used. The general characteristics of each group are described with the mean and standard deviation (SD). The significance level was set at $\alpha=0.05$. GraphPad Prism 5.0 software (GraphPad Inc., USA) was used to perform these statistical analyses. To investigate correlations (adjusted for age and sex) among various studied parameters, Spearman's rank correlation test was performed using SPSS ${ }^{\circledR}$ IBM software version 19 . The significance level was set at $\alpha=0.05$.

\section{Results}

3.1. Analysis of the Characteristics of Study Population. From a total of 1788 patients screened, 150 of them (30 patients per group) passed the research inclusion criteria. Table 2, which is extracted in part from our previous studies [21, $22,24]$, showed no significant differences between groups regarding gender. Fasting glucose and $\mathrm{HbAlc}$, as expected, were significantly higher in G1, confirming the poor glycemic control; these parameters were also higher in the G2 group than in nondiabetics (G3, G4, and G5). Insulin levels showed no significant differences between G1 and G2 groups. The HOMA index was significantly higher in the diabetic groups (G1 and G2) than in G3, G4, and G5. BMI, waist-to-hip ratio, and abdominal circumference were higher in diabetic groups (G1 and G2) than in the G5 group. As expected, the total cholesterol, LDL, and triglyceride levels were higher in the G1, G2, and G3 groups than G4 and G5 (Table 2).

Table 1 shows that periodontal tissue destruction (including bone loss) and local inflammation were significantly more severe in diabetics, particularly in the G1 group, which presented a high percentage of periodontal sites with bleeding on probing, probing depth $\geq 6 \mathrm{~mm}$, clinical attachment loss $\geq 5 \mathrm{~mm}$, and suppuration. The G2 group showed significant difference in relation to the presence of deeper periodontal sites when compared to groups without T2D (G3, G4, and G5).

3.2. Analysis of Gene Expression. Regarding gene expression analysis, as can be seen in Figure 1 (IL10 signaling pathway genes) and Figure 2 (IFNA and IFNG signaling pathway genes), IL10 and IFNA genes were significantly more highly expressed in patients with T2D and dyslipidemia (G1, G2, and G3). The opposite occurred with the IFNG gene, which was more highly expressed in the groups without dyslipidemia 

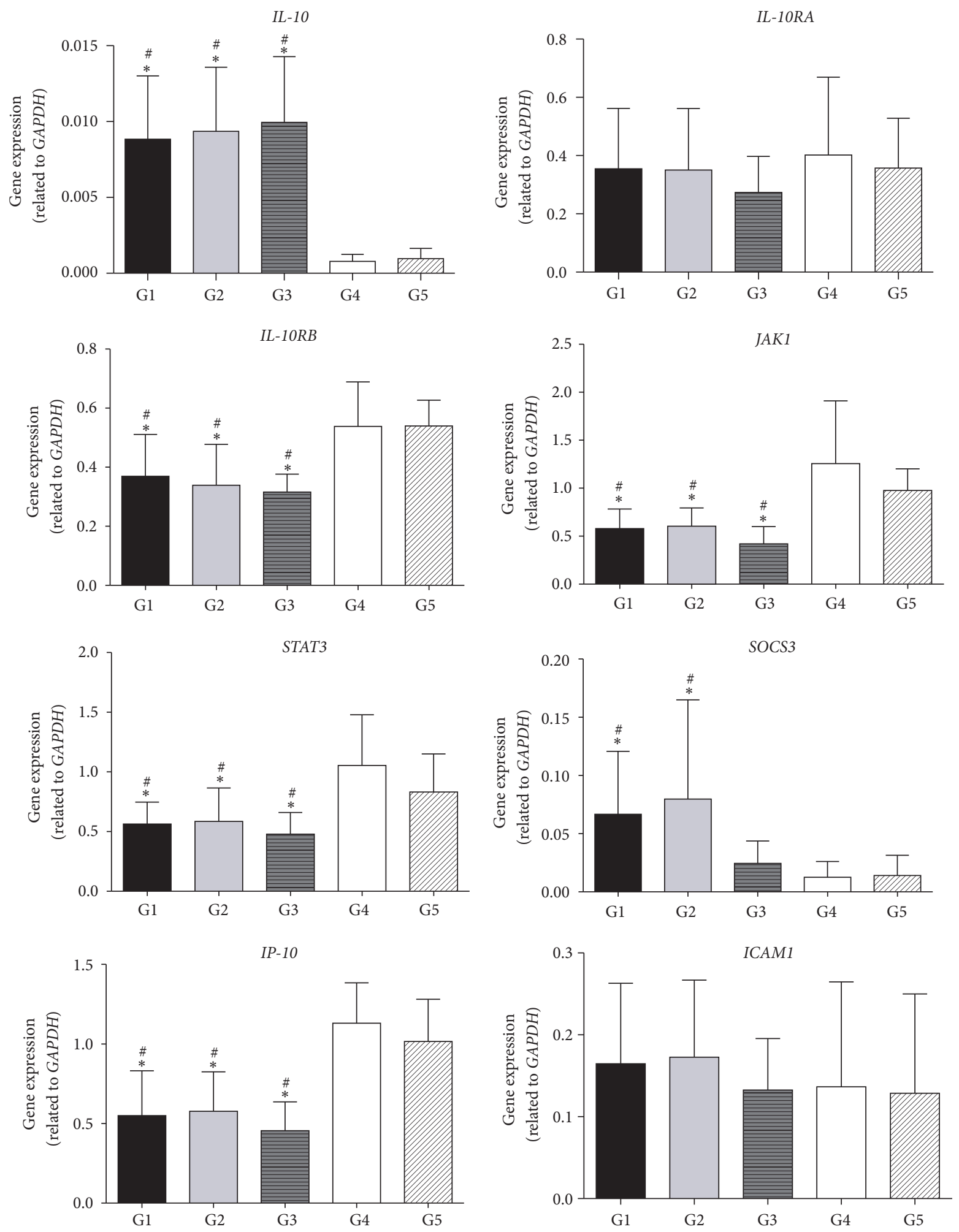

FIGURE 1: Signaling pathway of IL10 gene in groups G1, G2, G3, G4, and G5. All values were normalized to GAPDH. Data represent the mean \pm SD. ${ }^{\#} P \leq 0.05$ compared to G4 group; ${ }^{*} P \leq 0.05$ compared to group G5. Comparisons between all groups were performed by the Kruskal-Wallis test, and Dunn test was used to correct for multiple comparisons. 

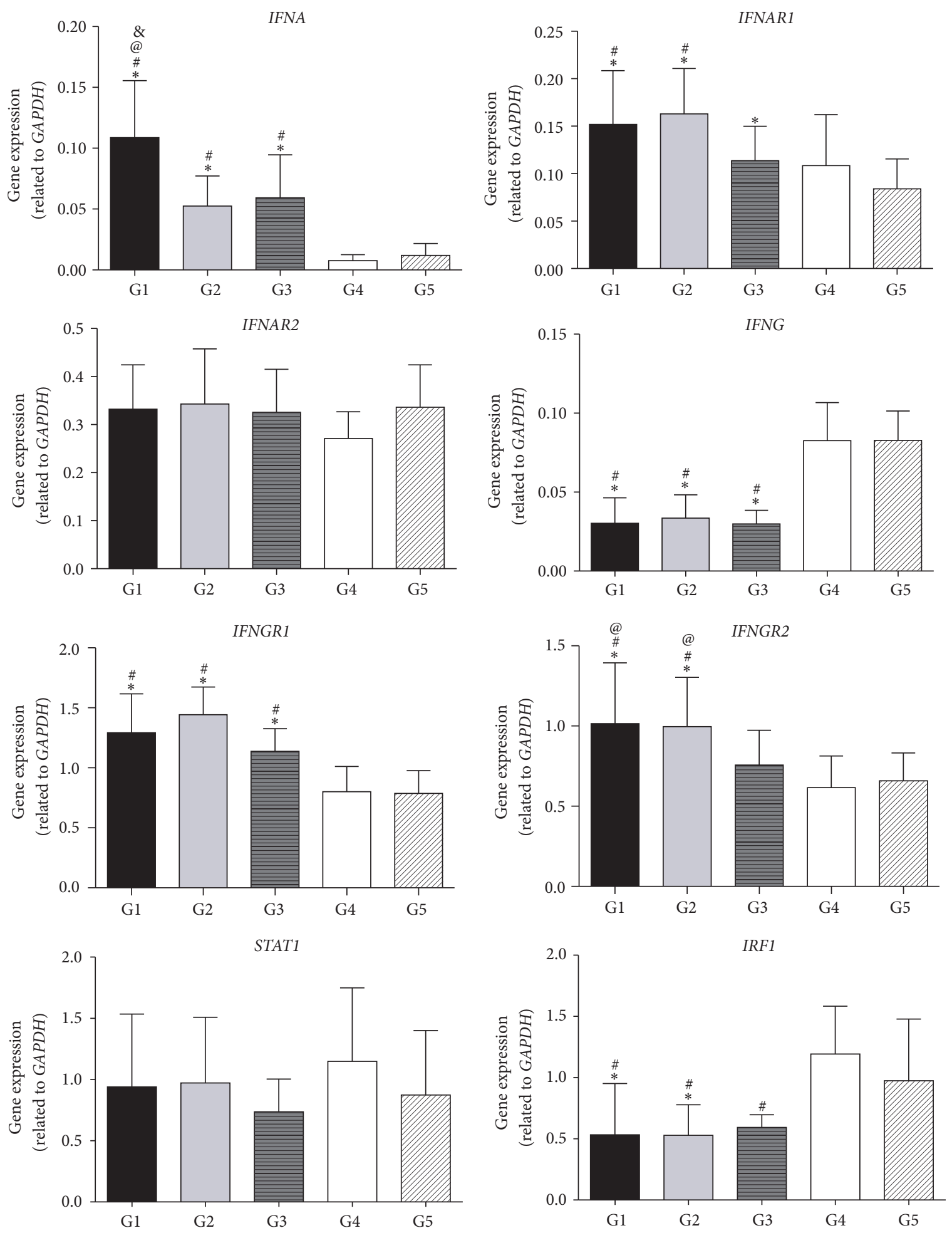

FIGURE 2: Signaling pathway of IFNA and IFNG genes in groups G1, G2, G3, G4, and G5. All values were normalized to GAPDH. Data represent the mean $\pm \mathrm{SD} .{ }^{\&} P \leq 0.05$ compared to G2; ${ }^{\circledR} P \leq 0.05$ compared to G3; ${ }^{\#} P \leq 0.05$ compared to G4; ${ }^{*} P \leq 0.05$ compared to G5. Comparisons between all groups were performed by the Kruskal-Wallis test, and Dunn test was used to correct for multiple comparisons. 
(G4 and G5) compared to G1, G2, and G3 (Figures 1 and 2). Considering the IL10 pathway genes, IL10 was expressed at a significantly higher level in dyslipidemic individuals (G1, G2, and G3) in comparison with G4 and G5, while the IL10RB, JAK1, STAT3, and IP10 genes showed the opposite lower expression (Figure 1). Moreover, SOCS3 was expressed at a significantly higher level in T2D patients (G1 and $\mathrm{G} 2$ ). Concerning genes of the interferon-alpha and -beta pathways, expression of the IFNG, IRF1, and JAK1 genes was significantly lower, while IFNA showed higher expression in dyslipidemic individuals in comparison with G4 and G5 groups (Figure 2).

3.3. Adjusted Correlation Analysis. Gene expression was significantly correlated with physical parameters and with glycemic and lipid profiles (Table 3 ). There was a significant positive correlation between IL10, IFNA, and SOCS3 genes with physical, glycemic, and lipid profiles, especially $\mathrm{HbAlc}$ (IFNA, $r=0.65$ ) and total cholesterol (IL10, $r=0.57$ ). Furthermore, some genes showed independent negative correlation with physical as well as glycemic and lipid profiles, especially triglycerides (IP10, $r=-0.55$ ) and total cholesterol (IFNG, $r=-0.54$; IRF1, $r=-0.49$; and JAK1, $r=-0.44$ ).

Correlation analyses between genes are presented in Table 4 . The IL10 gene correlated negatively with IP10, IRF1, STAT3, JAK1, and mainly IFNG $(r=-0.75)$. In addition, IL10 gene expression positively correlated with IFNA and SOCS3. The expression of IFNG gene was positively correlated mainly with the IP10 gene $(r=0.72)$ and negatively correlated with IFNA $(r=-0.57)$. Furthermore, IRF1 positively and strongly correlated with STAT3 and JAK1.

Increases in the percentage of the periodontal clinical parameters (visible plaque, marginal bleeding, BP, $\mathrm{PPD} \geq$ $6 \mathrm{~mm}, \mathrm{NI} \geq 5 \mathrm{~mm}$, and suppuration) indicate the severity of chronic periodontitis [27]. There was a positive correlation between the expression of IL10 and IFNA genes with periodontal clinical parameters, such as visible plaque, marginal bleeding, $\mathrm{BP}, \mathrm{PPD} \geq 6 \mathrm{~mm}, \mathrm{CAL} \geq 5 \mathrm{~mm}$, and suppuration. Moreover, there was a negative correlation between IFNG, IP10, and IRF1 genes with those same periodontal clinical parameters. As periodontal pocket depth increased $(P P D \geq$ $6 \mathrm{~mm}$ ), the expression of IL10 and IFNA genes increased, while the opposite was observed for the IFNG and IP10 genes (Table 5).

\section{Discussion}

To our knowledge, this is the first study to investigate the expression of genes belonging to the IL10 and interferonalpha and -gamma pathways in individuals affected by T2D, dyslipidemia, and CP. Surprisingly, we find difference in gene expression related to poor or good glycemic control of T2D only for the IFNA gene. The present results indicate that dyslipidemia seemed to influence systemic expression of important pro- and anti-inflammatory genes in individuals concomitantly affected by the multifactorial diseases of T2D, dyslipidemia, and CP. However, this does not mean that T2D and CP did not influence gene expression, since glucose and periodontal parameters were significantly correlated with expression of the investigated immune genes.

We demonstrated here that dyslipidemic patients had increased expression of the IL10 gene (Figure 1). In agreement, increased circulating IL-10 levels have been reported in obese [31, 32], T2D [33], coronary heart disease [34], and acute coronary syndrome [35] patients. Increased IL10 mRNA levels were shown in osteoblastic cells under high glucose concentration [36]. However, other studies have reported reduced levels of the anti-inflammatory IL-10 in dyslipidemic subjects, together with higher levels of proinflammatory cytokines [32, 37-39]. The mechanisms explaining the paradoxical findings are currently unclear. A possible explanation for our results may be that the increased IL10 gene expression may represent a delicate regulatory pathway to restore the homeostasis under inflammatory conditions. Thus, IL10 may be a surrogate marker of a heightened inflammatory process and act to counterregulate the effects of proinflammatory mediators $[35,40]$. In regard to the correlation analysis, we demonstrated that IL10 gene expression was significantly positively correlated with lipid parameters and also with physical and glycemic parameters. Similarly, Bassols et al. (2010) found that serum concentrations of IL-10 had a positive correlation with fasting triglycerides, weight, BMI, waist circumference, and waist-to-hip ratio [31].

SOCS3 is an important IL10-responsive gene, since SOCS-3 protein inhibits JAK/STAT-dependent signaling by blocking STAT phosphorylation, which inhibits the expression of many proinflammatory genes [41]. IL10 rapidly upregulates transcription of SOCS3 [41]. Proinflammatory cytokines may stimulate the production of SOCS-3, which in turn participates in a negative-feedback loop that modulates cytokine action. Both IFN-gamma and IL-10 rapidly induce SOCS3 gene expression in monocytes [41]. In this study, in agreement with the literature, there was a positive correlation between SOCS3 and IL10 genes (Table 4).

Data analysis indicated that T2D patients (G1 and G2 groups) had increased expression of the SOCS3 gene. Similarly, it was demonstrated that SOCS-3 has been implicated as a mediator of insulin resistance [42], and SOCS-3 protein expression was elevated in skeletal muscle of insulin resistant T2D [43]. It is noteworthy that SOCS3 expression is increased in mononuclear cells from healthy people in response to a high-fat, high-carbohydrate meal or following ingestion of glucose or cream $[44,45]$. Furthermore, SOCS3 correlation analyses demonstrated results compatible with those found for IL10; that is, significant positive correlations were observed between SOCS3 expression with glycemic profile and physical and lipid parameters (Table 3 ).

IFN-alpha has been widely employed in the treatment of various diseases, such as hematologic malignancies and hepatitis B [46, 47]. After beginning IFN-alpha treatment, serum lipids levels increased sharply [46-49]. Indeed, treating patients with this interferon caused marked changes in serum lipoprotein metabolism, leading to dyslipidemia [49]. Therefore, IFN-alpha seems to play an important role in lipid metabolism and accelerated atherosclerosis [50]. Endogenous IFN-alpha has been proposed to play a role in hypertriglyceridemia by its ability to promote hepatic lipogenesis 


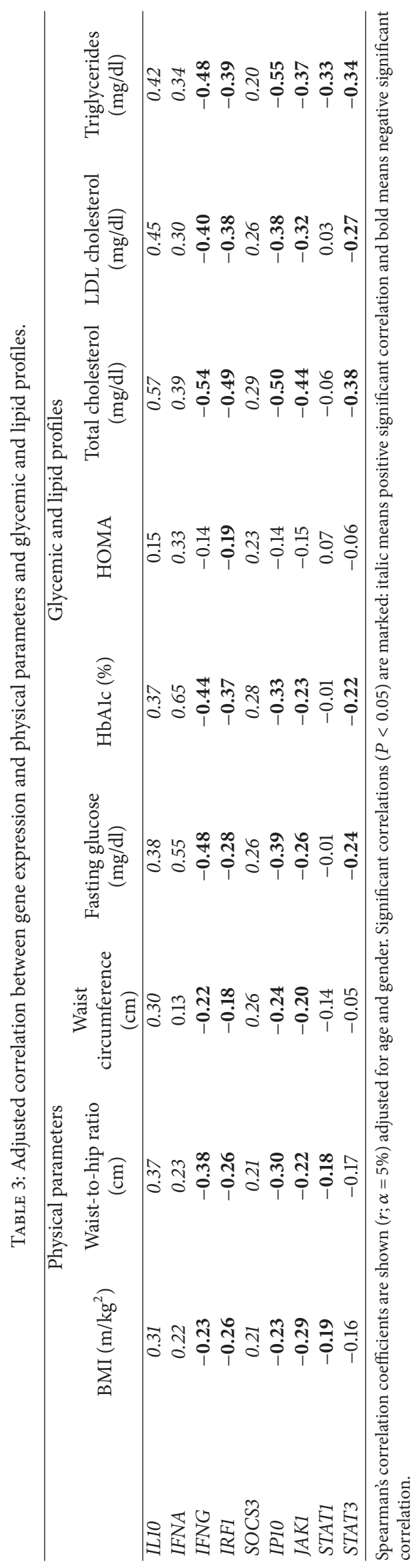


TABLE 4: Adjusted correlation of expressions between the investigated genes.

\begin{tabular}{|c|c|c|c|c|c|c|c|c|c|c|c|c|c|c|c|c|}
\hline & IL10 & IL10RA & IL10RB & $J A K 1$ & STAT1 & STAT3 & ICAM1 & IRF1 & SOCS3 & IP10 & $I F N G$ & IFNGR1 & IFNGR2 & IFNA & IFNAR1 & IFNAR2 \\
\hline IL10 & 1.00 & & & & & & & & & & & & & & & \\
\hline IL10RA & -0.15 & 1.00 & & & & & & & & & & & & & & \\
\hline IL10RB & -0.56 & 0.23 & 1.00 & & & & & & & & & & & & & \\
\hline$J A K 1$ & -0.59 & 0.44 & 0.63 & 1.00 & & & & & & & & & & & & \\
\hline STAT1 & -0.13 & 0.33 & 0.50 & 0.39 & 1.00 & & & & & & & & & & & \\
\hline STAT3 & -0.50 & 0.29 & 0.59 & 0.61 & 0.46 & 1.00 & & & & & & & & & & \\
\hline ICAM1 & 0.08 & 0.38 & 0.20 & 0.08 & 0.48 & 0.39 & 1.00 & & & & & & & & & \\
\hline IRF1 & -0.57 & 0.31 & 0.47 & 0.57 & 0.28 & 0.62 & 0.23 & 1.00 & & & & & & & & \\
\hline SOCS3 & 0.35 & 0.31 & -0.06 & -0.17 & 0.23 & -0.02 & 0.34 & -0.13 & 1.00 & & & & & & & \\
\hline IP10 & -0.67 & 0.13 & 0.64 & 0.62 & 0.37 & 0.48 & 0.04 & 0.49 & -0.22 & 1.00 & & & & & & \\
\hline$I F N G$ & -0.75 & 0.07 & 0.57 & 0.56 & 0.20 & 0.52 & -0.03 & 0.51 & -0.26 & 0.72 & 1.00 & & & & & \\
\hline IFNGR1 & 0.64 & 0.01 & -0.33 & -0.43 & 0.03 & -0.36 & 0.15 & -0.53 & 0.51 & -0.44 & -0.59 & 1.00 & & & & \\
\hline IFNGR2 & 20.44 & -0.10 & -0.15 & -0.32 & 0.05 & -0.24 & 0.10 & -0.43 & 0.33 & -0.29 & -0.37 & 0.65 & 1.00 & & & \\
\hline IFNA & 0.49 & 0.06 & -0.37 & -0.43 & -0.02 & -0.35 & 0.13 & -0.48 & 0.36 & -0.45 & -0.57 & 0.48 & 0.45 & 1.00 & & \\
\hline IFNAR1 & 0.38 & 0.13 & -0.14 & -0.07 & 0.09 & -0.14 & 0.20 & -0.39 & 0.39 & -0.21 & -0.35 & 0.67 & 0.48 & 0.36 & 1.00 & \\
\hline IFNAR2 & 20.18 & 0.17 & -0.07 & -0.13 & 0.08 & -0.09 & 0.23 & -0.24 & 0.41 & -0.16 & -0.23 & 0.47 & 0.48 & 0.40 & 0.52 & 1.00 \\
\hline
\end{tabular}

Spearman's correlation coefficients are shown $(r ; \alpha=5 \%)$ adjusted for age and gender. Significant correlations $(P<0.05)$ are marked: italic means positive significant correlation and bold means negative significant correlation.

and reduced triglyceride clearance [51]. In agreement, our present results show that IFNA expression was higher in groups with dyslipidemia (G1, G2, and G3). Furthermore, IFNA expression positively correlated with LDL cholesterol, triglycerides, and total cholesterol (Table 3). Moreover, the expression of IFNA was even higher in T2D patients with poor glycemic control (Figure 2), and a strong positive correlation was found between expression of this gene and the percentage of HbAlc. The relationship between IFNA gene expression and $\mathrm{T} 2 \mathrm{D}$ is presented here for the first time in the literature; further investigation is indicated.

The literature demonstrates that IFNA and IFNG exert opposing effects on the regulation of cytokine expression, including IL-10 $[52,53]$. The enhancement of IL-10 production by IFN-alpha appears to be tightly regulated, since IFN-alpha has a potent effect on the production of IL-10 by activated monocytes and T-helper cells [53]. Here, we found similar results, considering that there was higher expression of IFNA and IL10 genes in the same groups (Figures 1 and 2), and there was positive correlation between these genes.

In contrast to the ILIO and IFNA genes, the present study demonstrates lower expression of IFNG in the groups composed by patients with dyslipidemia (G1, G2, and G3). There was strong negative correlation between IL10 and IFNG, indicating a lower expression of IFNG, accompanied by higher expression of IL10, in patients with systemic inflammatory status. IFN-gamma is a major proinflammatory cytokine produced by Thl cells and natural killer cells and is responsible for macrophage activation and increased production of IL-1 and TNF-alpha [54-56]. Th1 and Th2 cells inhibit each other; for example, IL-10, which is produced by Th2 cells, inhibits Th1 cells, and IFN-gamma inhibits the activation of Th2 [57]. IL10 is a potent inhibitor of the activity of monocytes/macrophages, including oxidative stress and the production of cytokines, such as TNF-alpha, IL-1, and
IL-6 $[58,59]$. TNF-alpha is an important cofactor for the induction of IFN-gamma by Th1 cells, while the ability of IL-10 to inhibit TNF-alpha production has been one of the mechanisms by which IL-10 inhibits IFN-gamma [60, 61]. Therefore, our results agree with these concepts.

PBMCs containing phytohemagglutinin-stimulated lymphocytes of dyslipidemic patients have been shown to release higher IFN-gamma than controls [62]. Since IFN-gamma has been detected in human atherosclerotic plaques, it is accepted that IFN-gamma is a proatherogenic cytokine, and its action occurs through the activation of macrophages, with subsequent accumulation of lipids [63]. In disagreement with these studies, other studies have demonstrated that (i) severe hypercholesterolemia in mice decreases IFN-gamma response and induces IL-10 response [64]; (ii) PBMCs incubated in high glucose concentrations produced higher levels of TNF-alpha, IL-1beta, and IL-6, while IFN-gamma did not change [65]; (iii) studies with whole blood or PBMCs of T2D patients with and without tuberculosis reported decrease in IFN-gamma production [66-68]. Similarly, we found a negative correlation between the IFNG gene with glycemic and lipid profiles; furthermore, the patients with dyslipidemia (G1, G2, and G3) expressed lower IFNG mRNA levels than systemically healthy patients (G4 and G5).

IFN-gamma demonstrates synergism with proinflammatory cytokines, such as ILl-beta, and also induces the expression of interferon-gamma-induced protein-10 (IP-10, also called CXCL10) $[41,69,70]$. In this study, the IP10 gene expression was strongly positively correlated with the IFNG gene $(r=0.72)$. IL-10 is able to inhibit the expression of IP10, which agrees with the strong negative correlation found between IP10 and IL10 $(r=-0.67)$. This occurs because IL10 and IFN-gamma compete for intracellular mechanisms, and IL-10 causes inhibition of STAT-1 activation in the IFNgamma signaling pathway [52]. 


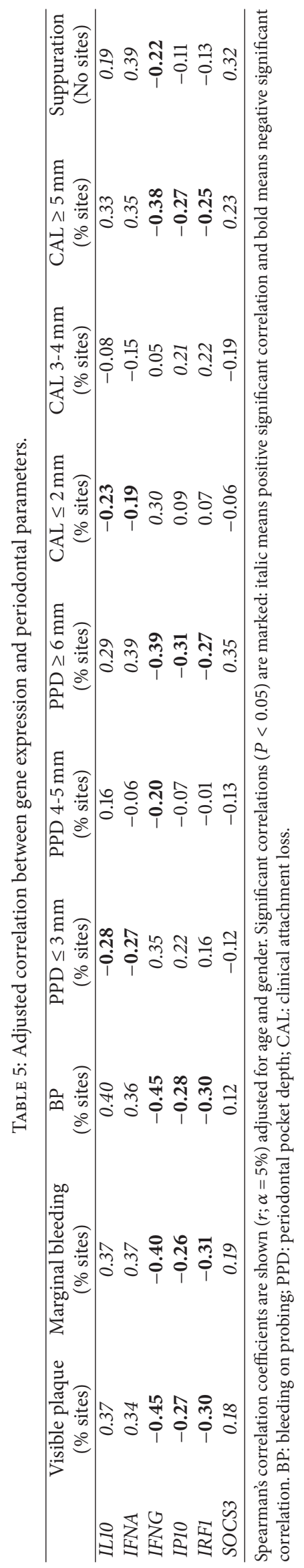


A significant reduction of circulating IP-10 concentration was observed as a consequence of triglyceride ingestion [71]. In our study, IP10 gene expression negatively correlated with T2D and dyslipidemia parameters. In addition, IP10 gene expression was significantly lower in patients with dyslipidemia (G1, G2, and G3 groups).

Similar to IP10, intercellular adhesion molecule 1 (ICAM1) is also stimulated by IFN-gamma, while IL10 can inhibit its expression [41, 70]. ICAM1 is an important inflammatory marker, which was associated with metabolic syndrome by multiple linear regression models [72]. However, the results obtained here demonstrate that the ICAM 1 gene was not differentially expressed between the five groups.

Interferon regulatory factor 1 (IRF1) is an important signaling protein in the interferon pathway $[73,74]$, in which IFN-gamma is able to activate its transcription [75]. In the same way of IFNG, IRF1 was higher in patients without dyslipidemia. Concerning the STAT1 gene, it is under direct transcriptional regulation by IFNs, but it may also be regulated by $I R F 1$ positive-feedback mechanisms, leading to an increase in STAT1 gene expression [76-78]. In agreement, here we observed a positive correlation between STAT1 and IRF1.

A positive correlation was found between JAK1 and STAT3, as well as between JAK1 and STAT1. This finding was expected, since these molecules belong to the JAK/STAT signaling pathway [41]. As mentioned, patients without dyslipidemia and diabetes have an increased expression of IFNgamma [64-68], which activates the JAK/STAT signaling pathway. In agreement, here we observed a positive correlation between IFNG with STAT1, STAT3 and JAK1 (Table 4). Similar to IFNG, the expressions of JAK1 and STAT3 were statistically lower in subjects with dyslipidemia (G1, G2, and G3), and significant negative correlations were found between these genes and lipid parameters. Interestingly, the expression of IL1ORB differed from that of IL10, as well as between IFNG and IFNGR1 and IFNGR2. We did not find in the literature potential explanations for this observation, but similar results were observed in a previous study of our group related to patients with Down syndrome and periodontal disease [29].

Dyslipidemia and type 2 diabetes have a dysregulatory effect on immune system cells and on wound healing, and, as a result, they increase the susceptibility to periodontitis and other infections [79]. Despite the presence of chronic periodontitis not appearing to influence the systemic expression of the genes studied, this study showed a correlation between lower expression of IFNG and IP10 and higher expression of ILIO and IFNA with the severity of chronic periodontitis (higher percentage of visible plaque, marginal bleeding, $\mathrm{BP}, \mathrm{PPD} \geq 6 \mathrm{~mm}, \mathrm{CAL} \geq 5 \mathrm{~mm}$, and suppuration). These results suggest that the systemic expression of these genes may directly influence the periodontal tissue. Moreover, the glycemic control and lipid parameters could be related to the progression of CP. It is important to emphasize that the simplistic classification of proinflammatory or anti-inflammatory cytokines has been challenged by extensive experimental data. In fact, numerous cytokines have both proinflammatory and anti-inflammatory properties, dependent upon the target cells, the cytokine amount, and the activated signaling pathway [35].

The present study has some limitations, including the lack of longitudinal data-tracking of diseases, and no quantification of proteins, such as IL-10 and IFN-gamma in the plasma of patients. In addition, we did not separate cells of the PBMCs, but we think that the gene expression findings were not influenced by a specific cell type because we assessed the counts of lymphocytes, neutrophils, eosinophils, and monocytes in each patient, and they were statistically similar between groups. Despite the mentioned limitations, they did not affect the confidence of the results found.

\section{Conclusions}

Our study provides evidence that leads to the following conclusions: (i) dyslipidemia seemed to be the primary disease associated mainly with increase of IL10 and IFNA and decrease of IFNG, IP10, IRF1, JAK1, and STAT3 gene expression; (ii) T2D and CP also participate in gene expression, since glucose and periodontal parameters significantly correlated with the mRNA levels of the investigated immune genes.

These findings provide evidence that inflammatory dysregulation associates with dyslipidemia and demonstrated the complex regulation of the systemic immune response, mainly when dyslipidemia is associated with T2D and CP. Moreover, we observed that dyslipidemic patients also affected by poorly controlled diabetes presented increased severity of periodontitis, collectively negatively affecting health and quality of life.

\section{Competing Interests}

The authors declare that they have no competing interests.

\section{Authors' Contributions}

Raquel Mantuaneli Scarel-Caminaga and Silvana Regina Perez Orrico conceived and coordinated the study. Sâmia Cruz Tfaile Corbi, Alliny De Souza Bastos, and Silvana Regina Perez Orrico examined and selected the patients. Raquel Alves Dos Santos and Catarina Satie Takahashi helped in the study design, mainly with the methods. Bárbara Scoralick Villela and Rafael Nepomuceno carried out the RTqPCR reactions and performed statistical analysis. Raquel Mantuaneli Scarel-Caminaga and Rafael Nepomuceno wrote the manuscript. Sâmia Cruz Tfaile Corbi and Silvana Regina Perez Orrico helped with the results analyses and critically corrected the manuscript. All authors read and approved the final manuscript.

\section{Acknowledgments}

The authors would like to acknowledge the assistance of Dr. David A. Barrow in text revision. This study was supported by the Foundation for Research Support of State of São Paulo, FAPESP, Grant nos. 2007/08362-8, 2009/162339, and 2010/10882-2, and the Coordination of Improvement 
of Higher Education Students of the Brazilian Ministry of Education (CAPES).

\section{References}

[1] O. M. Andriankaja, J. Galicia, G. Dong, W. Xiao, F. Alawi, and D. T. Graves, "Gene expression dynamics during diabetic periodontitis," Journal of Dental Research, vol. 91, no. 12, pp. 1160-1165, 2012.

[2] American Diabetes Association, "Diagnosis and classification of diabetes mellitus," Diabetes Care, vol. 33, supplement 1, pp. S62-S69, 2010.

[3] A. D. Mooradian, "Dyslipidemia in type 2 diabetes mellitus," Nature Clinical Practice Endocrinology \& Metabolism, vol. 5, no. 3, pp. 150-159, 2009.

[4] K. R. Feingold and M. D. Siperstein, "Diabetic vascular disease," Advances in Internal Medicine, vol. 31, pp. 309-340, 1986.

[5] J. A. Farmer, "Diabetic dyslipidemia and atherosclerosis: evidence from clinical trials," Current Diabetes Reports, vol. 8, no. 1, pp. 71-77, 2008.

[6] M. P. Solano and R. B. Goldberg, "Management of dyslipidemia in diabetes," Cardiology in Review, vol. 14, no. 3, pp. 125-135, 2006.

[7] L. Wu and K. G. Parhofer, "Diabetic dyslipidemia," Metabolism: Clinical and Experimental, vol. 63, no. 12, pp. 1469-1479, 2014.

[8] J.-B. Lee, H.-Y. Yi, and K.-H. Bae, "The association between periodontitis and dyslipidemia based on the fourth Korea National Health and Nutrition Examination Survey," Journal of Clinical Periodontology, vol. 40, no. 5, pp. 437-442, 2013.

[9] G. C. Armitage, "Development of a classification system for periodontal diseases and conditions," Northwest dentistry, vol. 79, 2000.

[10] W. E. Moore and L. V. Moore, "The bacteria of periodontal diseases," Periodontology 2000, vol. 5, article 66, 1994.

[11] R. C. Page and K. S. Kornman, "The pathogenesis of human periodontitis: an introduction.”, Periodontology 2000, vol. 14, pp. 9-11, 1997.

[12] J. L. Ebersole, D. Cappelli, G. Mott, L. Kesavalu, S. C. Holt, and R. E. Singer, "Systemic manifestations of periodontitis in the non-human primate," Journal of Periodontal Research, vol. 34, no. 7, pp. 358-362, 1999.

[13] F. Awartani and F. Atassi, "Evaluation of periodontal status in subjects with hyperlipidemia," Journal of Contemporary Dental Practice, vol. 11, no. 2, pp. 33-40, 2010.

[14] B. Chee, B. Park, and P. M. Bartold, "Periodontitis and type II diabetes: a two-way relationship," International Journal of Evidence-Based Healthcare, vol. 11, no. 4, pp. 317-329, 2013.

[15] P. M. Preshaw, A. L. Alba, D. Herrera et al., "Periodontitis and diabetes: a two-way relationship," Diabetologia, vol. 55, pp. 2131, 2012 .

[16] H. Loe, "Periodontal disease: the sixth complication of diabetes mellitus," Diabetes Care, vol. 16, no. 1, pp. 329-334, 1993.

[17] H. K. Lu and P. C. Yang, "Cross-Sectional analysis of different variables of patients with non-insulin dependent diabetes and their periodontal status," International Journal of Periodontics and Restorative Dentistry, vol. 24, no. 1, pp. 71-79, 2004.

[18] B. L. Mealey and T. W. Oates, "Diabetes mellitus and periodontal diseases," Journal of Periodontology, vol. 77, no. 8, pp. 1289-1303, 2006.

[19] P. N. Papapanou, "Periodontal diseases: epidemiology," Annals of periodontology, vol. 1, no. 1, pp. 1-36, 1996.
[20] P. Bullon, J. M. Morillo, M. C. Ramirez-Tortosa, J. L. Quiles, H. N. Newman, and M. Battino, "Metabolic syndrome and periodontitis: is oxidative stress a common link?" Journal of Dental Research, vol. 88, no. 6, pp. 503-518, 2009.

[21] A. S. Bastos, D. T. Graves, A. P. D. M. Loureiro et al., "Lipid peroxidation is associated with the severity of periodontal disease and local inflammatory markers in patients with type 2 diabetes," Journal of Clinical Endocrinology and Metabolism, vol. 97, no. 8, pp. E1353-E1362, 2012.

[22] S. C. T. Corbi, A. S. Bastos, S. R. P. Orrico et al., "Elevated micronucleus frequency in patients with type 2 diabetes, dyslipidemia and periodontitis," Mutagenesis, vol. 29, no. 6, pp. 433-439, 2014.

[23] R. J. L. Bondar and D. C. Mead, "Evaluation of glucose-6phosphate dehydrogenase from Leuconostoc mesenteroides in the hexokinase method for determining glucose in serum," Clinical Chemistry, vol. 20, no. 5, pp. 586-590, 1974.

[24] A. de Souza Bastos, D. T. Graves, A. P. de Melo Loureiro et al., "Diabetes and increased lipid peroxidation are associated with systemic inflammation even in well-controlled patients," Journal of Diabetes and Its Complications, vol. 30, no. 8, pp. 15931599, 2016.

[25] D. R. Matthews, J. P. Hosker, A. S. Rudenski, B. A. Naylor, D. F. Treacher, and R. C. Turner, "Homeostasis model assessment: insulin resistance and $\beta$-cell function from fasting plasma glucose and insulin concentrations in man," Diabetologia, vol. 28, no. 7, pp. 412-419, 1985.

[26] J. I. Cleeman, "Executive summary of the third report of the National Cholesterol Education Program (NCEP) expert panel on detection, evaluation, and treatment of high blood cholesterol in adults (adult treatment panel III)," Journal of the American Medical Association, vol. 285, no. 19, pp. 2486-2497, 2001.

[27] “1999 International International Workshop for a Classification of Periodontal Diseases and Conditions. Papers. Oak Brook, Illinois, October 30-November 2, 1999," Annals of Periodontology, vol. 4, no. 1, pp. il-il12, 1999.

[28] P. A. Koromantzos, K. Makrilakis, X. Dereka, N. Katsilambros, I. A. Vrotsos, and P. N. Madianos, "A randomized, controlled trial on the effect of non-surgical periodontal therapy in patients with type 2 diabetes. Part I: effect on periodontal status and glycaemic control," Journal of Clinical Periodontology, vol. 38, no. 2, pp. 142-147, 2011.

[29] L. B. Cavalcante, M. H. Tanaka, J. R. Pires et al., "Expression of the interleukin-10 signaling pathway genes in individuals with down syndrome and periodontitis," Journal of Periodontology, vol. 83, no. 7, pp. 926-935, 2012.

[30] M. H. Tanaka, E. M. A. Giro, L. B. Cavalcante et al., "Expression of interferon- $\gamma$, interferon- $\alpha$ and related genes in individuals with Down syndrome and periodontitis," Cytokine, vol. 60, no. 3, pp. 875-881, 2012.

[31] J. Bassols, P. Botas, J. M. Moreno-Navarrete et al., "Environmental and genetic factors influence the relationship between circulating il-10 and obesity phenotypes," Obesity, vol. 18, no. 3, pp. 611-618, 2010.

[32] K. Esposito, A. Pontillo, F. Giugliano et al., "Association of low interleukin-10 levels with the metabolic syndrome in obese women," Journal of Clinical Endocrinology and Metabolism, vol. 88, no. 3, pp. 1055-1058, 2003.

[33] M. N. Pham, M. I. Hawa, C. Pfleger et al., "Pro- and antiinflammatory cytokines in latent autoimmune diabetes in 
adults, type 1 and type 2 diabetes patients: action LADA 4," Diabetologia, vol. 54, no. 7, pp. 1630-1638, 2011.

[34] J. Watanabe, V. Grijalva, S. Hama et al., "Hemoglobin and its scavenger protein haptoglobin associate with ApoA-1containing particles and influence the inflammatory properties and function of high density lipoprotein," Journal of Biological Chemistry, vol. 284, no. 27, pp. 18292-18301, 2009.

[35] J. Liu, Y. J. Jia, X. L. Li et al., "Serum interleukin-10 levels and adverse events in patients with acute coronary syndrome: a systematic review and meta-analysis," Chinese Medical Journal, vol. 127, no. 1, pp. 150-156, 2014.

[36] A. García-Hernández, H. Arzate, I. Gil-Chavarría, R. Rojo, and L. Moreno-Fierros, "High glucose concentrations alter the biomineralization process in human osteoblastic cells," Bone, vol. 50, no. 1, pp. 276-288, 2012.

[37] K. M. Choi, O. H. Ryu, K. W. Lee et al., "Serum adiponectin, interleukin-10 levels and inflammatory markers in the metabolic syndrome," Diabetes Research and Clinical Practice, vol. 75, no. 2, pp. 235-240, 2007.

[38] I. Narverud, T. Ueland, M. S. Nenseter et al., "Children with familial hypercholesterolemia are characterized by an inflammatory imbalance between the tumor necrosis factor $\alpha$ system and interleukin-10," Atherosclerosis, vol. 214, no. 1, pp. 163-168, 2011.

[39] E. van Exel, J. Gussekloo, A. J. M. De Craen, M. Frölich, A. B.-V. D. Wiel, and R. G. J. Westendorp, "Low production capacity of interleukin-10 associates with the metabolic syndrome and type 2 diabetes: the Leiden 85-plus study," Diabetes, vol. 51, no. 4, pp. 1088-1092, 2002.

[40] T. Y. Jang, K.-S. Kim, C.-S. Park et al., "Exposure to hypergravity increases serum interleukin-5 and pulmonary infiltration in mice with allergic asthma," Central European Journal of Immunology, vol. 39, no. 4, pp. 434-440, 2014.

[41] R. P. Donnelly, H. Dickensheets, and D. S. Finbloom, "The interleukin-10 signal transduction pathway and regulation of gene expression in mononuclear phagocytes," Journal of Interferon and Cytokine Research, vol. 19, no. 6, pp. 563-573, 1999.

[42] J. J. Senn, P. J. Klover, I. A. Nowak et al., "Suppressor of cytokine signaling-3 (SOCS-3), a potential mediator of interleukin-6dependent insulin resistance in hepatocytes," The Journal of Biological Chemistry, vol. 278, no. 16, pp. 13740-13746, 2003.

[43] J. Rieusset, K. Bouzakri, E. Chevillotte et al., "Suppressor of cytokine signaling 3 expression and insulin resistance in skeletal muscle of obese and type 2 diabetic patients," Diabetes, vol. 53, no. 9, pp. 2232-2241, 2004.

[44] H. Ghanim, S. Abuaysheh, C. L. Sia et al., "Increase in plasma endotoxin concentrations and the expression of toll-like receptors and suppressor of cytokine signaling-3 in mononuclear cells after a high-fat, high-carbohydrate meal: implications for insulin resistance," Diabetes Care, vol. 32, no. 12, pp. 2281-2287, 2009.

[45] R. Deopurkar, H. Ghanim, J. Friedman et al., "Differential effects of cream, glucose, and orange juice on inflammation, endotoxin, and the expression of toll-like receptor-4 and suppressor of cytokine signaling-3," Diabetes Care, vol. 33, no. 5, pp. 991-997, 2010.

[46] E. C. Alexandropoulos, G. J. Kontochristopoulos, and N. Zakopoulou, "Hypertriglyceridaemia during low-dose interferon alpha-2b treatment in a patient with Kaposi's sarcoma," Dermatology, vol. 202, no. 4, 2001.

[47] C. Fernández-Miranda, G. Castellano, C. Guijarro et al., "Lipoprotein changes in patients with chronic hepatitis C treated with interferon- $\alpha$," The American Journal of Gastroenterology, vol. 93, no. 10, pp. 1901-1904, 1998.

[48] D. Sgarabotto, F. Vianello, P. M. Stefani et al., "Hypertriglyceridemia during long-term interferon- $\alpha$ therapy in a series of hematologic patients," Journal of Interferon and Cytokine Research, vol. 17, no. 5, pp. 241-244, 1997.

[49] E. Shinohara, S. Yamashita, S. Kihara et al., "Interferon alpha induces disorder of lipid metabolism by lowering postheparin lipases and cholesteryl ester transfer protein activities in patients with chronic hepatitis C," Hepatology, vol. 25, no. 6, pp. 1502-1506, 1997.

[50] Z. Levy, R. Rachmani, S. Trestman et al., "Low-dose interferon$\alpha$ accelerates atherosclerosis in an LDL receptor-deficient mouse model," European Journal of Internal Medicine, vol. 14, no. 8, pp. 479-483, 2003.

[51] C. Grunfeld, M. Pang, W. Doerrler, J. K. Shigenaga, P. Jensen, and K. R. Feingold, "Lipids, lipoproteins, triglyceride clearance, and cytokines in human immunodeficiency virus infection and the acquired immunodeficiency syndrome," Journal of Clinical Endocrinology and Metabolism, vol. 74, no. 5, pp. 1045-1052, 1992.

[52] S. Ito, P. Ansari, M. Sakatsume et al., "Interleukin-10 inhibits expression of both interferon $\alpha$ - and interferon $\gamma$-induced genes by suppressing tyrosine phosphorylation of STAT1," Blood, vol. 93, no. 5, pp. 1456-1463, 1999.

[53] M. J. Aman, T. Tretter, I. Eisenbeis et al., "Interferon- $\alpha$ stimulates production of interleukin-10 in activated CD4+ T cells and monocytes," Blood, vol. 87, no. 11, pp. 4731-4736, 1996.

[54] S. A. Huber, P. Sakkinen, C. David, M. K. Newell, and R. P. Tracy, " $\mathrm{T}$ helper-cell phenotype regulates atherosclerosis in mice under conditions of mild hypercholesterolemia," Circulation, vol. 103, no. 21, pp. 2610-2616, 2001.

[55] S.-J. Lin, J.-Y. Wang, L. B. Klickstein et al., "Lack of ageassociated LFA-1 up-regulation and impaired ICAM-1 binding in lymphocytes from patients with Down syndrome," Clinical and Experimental Immunology, vol. 126, no. 1, pp. 54-63, 2001.

[56] Y.-C. Lin, M.-C. Lu, C. Lin et al., "Activation of IFN$\gamma /$ STAT/IRF-1 in hepatic responses to Klebsiella pneumoniae infection," PLoS ONE, vol. 8, no. 11, Article ID e79961, 2013.

[57] N. E. Street and T. R. Mosmann, "Functional diversity of T lymphocytes due to secretion of different cytokine patterns," FASEB Journal, vol. 5, no. 2, pp. 171-177, 1991.

[58] R. T. Gazzinelli, I. P. Oswald, S. L. James, and A. Sher, "IL-10 inhibits parasite killing and nitrogen oxide production by IFN$\gamma$-activated macrophages," Journal of Immunology, vol. 148, no. 6, pp. 1792-1796, 1992.

[59] P. Ralph, I. Nakoinz, A. Sampson-Johannes et al., "IL-10, T lymphocyte inhibitor of human blood cell production of IL-1 and tumor necrosis factor," Journal of Immunology, vol. 148, no. 3, pp. 808-814, 1992.

[60] A. D’Andrea, M. Aste-Amezaga, N. M. Valiante, X. Ma, M. Kubin, and G. Trinchieri, "Interleukin 10 (IL-10) inhibits human lymphocyte interferon gamma-production by suppressing natural killer cell stimulatory factor/IL-12 synthesis in accessory cells," Journal of Experimental Medicine, vol. 178, no. 3, article 1041, 1993.

[61] J. C. Wherry, R. D. Schreiber, and E. R. Unanue, "Regulation of gamma interferon production by natural killer cells in scid mice: roles of tumor necrosis factor and bacterial stimuli," Infection and Immunity, vol. 59, no. 5, pp. 1709-1715, 1991.

[62] B. Okopień, R. Krysiak, J. Kowalski et al., "The effect of statins and fibrates on interferon- $\gamma$ and interleukin- 2 release in patients 
with primary type II dyslipidemia," Atherosclerosis, vol. 176, no. 2, pp. 327-335, 2004.

[63] H. W. Murray, "Interferon-gamma, the activated macrophage, and host defense against microbial challenge," Annals of Internal Medicine, vol. 108, no. 4, pp. 595-608, 1988.

[64] A.-K. L. Robertson, X. Zhou, B. Strandvik, and G. K. Hansson, "Severe hypercholesterolaemia leads to strong Th2 responses to an exogenous antigen," Scandinavian Journal of Immunology, vol. 59, no. 3, pp. 285-293, 2004.

[65] E. Lachmandas, F. Vrieling, L. G. Wilson et al., "The effect of hyperglycaemia on in vitro cytokine production and macrophage infection with mycobacterium tuberculosis," PLoS ONE, vol. 10, no. 2, Article ID e0117941, 2015.

[66] N. P. Kumar, R. Sridhar, V. V. Banurekha et al., “Type 2 diabetes mellitus coincident with pulmonary tuberculosis is associated with heightened systemic type 1 , type 17 , and other proinflammatory cytokines," Annals of the American Thoracic Society, vol. 10, no. 5, pp. 441-449, 2013.

[67] K. S. Tan, K. O. Lee, K. C. Low et al., "Glutathione deficiency in type 2 diabetes impairs cytokine responses and control of intracellular bacteria," The Journal of Clinical Investigation, vol. 122, no. 6, pp. 2289-2300, 2012.

[68] A. Ogbera, A. Azenabor, O. A. Ogundahunsi, A. O. Ekun, and E. N. Adejumo, "Cytokines, Type 2 DM and the Metabolic Syndrome," Nigerian quarterly journal of hospital medicine, vol. 23, no. 4, pp. 318-322, 2013.

[69] S. J. Burke, M. R. Goff, D. Lu, D. Proud, M. D. Karlstad, and J. J. Collier, "Synergistic expression of the CXCL10 gene in response to IL- $1 \beta$ and IFN- $\gamma$ involves NF- $\kappa$ B, phosphorylation of STAT1 at Tyr701, and acetylation of histones H3 and H4," Journal of Immunology, vol. 191, no. 1, pp. 323-336, 2013.

[70] K. W. Moore, R. De Waal Malefyt, R. L. Coffman, and A. O'Garra, "Interleukin-10 and the interleukin-10 receptor," Annual Review of Immunology, vol. 19, pp. 683-765, 2001.

[71] A. Schmid, M. Bala, S. Leszczak, I. Ober, C. Buechler, and T. Karrasch, "Pro-inflammatory chemokines CCL2, chemerin, IP10 and RANTES in human serum during an oral lipid tolerance test," Cytokine, vol. 80, pp. 56-63, 2016.

[72] D. Dallmeier, M. G. Larson, R. S. Vasan et al., "Metabolic syndrome and inflammatory biomarkers: a community-based cross-sectional study at the Framingham Heart Study," Diabetology and Metabolic Syndrome, vol. 4, no. 1, article 28, 2012.

[73] M. Flodström and D. L. Eizirik, "Interferon- $\gamma$-induced interferon regulatory factor-1 (IRF-1) expression in rodent and human islet cells precedes nitric oxide production," Endocrinology, vol. 138, no. 7, pp. 2747-2753, 1997.

[74] T. Tamura, H. Yanai, D. Savitsky, and T. Taniguchi, "The IRF family transcription factors in immunity and oncogenesis," Annual Review of Immunology, vol. 26, pp. 535-584, 2008.

[75] T. Taniguchi, K. Ogasawara, A. Takaoka, and N. Tanaka, "IRF family of transcription factors as regulators of host defense," Annual Review of Immunology, vol. 19, pp. 623-655, 2001.

[76] J. Doly, A. Civas, S. Navarro, and G. Uze, “Type I interferons: expression and signalization," Cellular and Molecular Life Sciences, vol. 54, no. 10, pp. 1109-1121, 1998.

[77] A. Lehtonen, S. Matikainen, and I. Julkunen, "Interferons upregulate STAT1, STAT2, and IRF family transcription factor gene expression in human peripheral blood mononuclear cells and macrophages," The Journal of Immunology, vol. 159, no. 2, pp. 794-803, 1997.
[78] A. Lehtonen, R. Lund, R. Lahesmaa, I. Julkunen, T. Sareneva, and S. Matikainen, "IFN- $\alpha$ and IL-12 activate IFN regulatory factor 1 (IRF-1), IRF-4, and IRF-8 gene expression in human NK and T cells," Cytokine, vol. 24, no. 3, pp. 81-90, 2003.

[79] O. Fentoglu and F. Y. Bozkurt, "The bi-directional relationship between periodontal disease and hyperlipidemia," European Journal of Dentistry, vol. 2, pp. 142-146, 2008. 


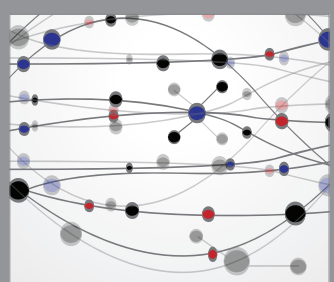

The Scientific World Journal
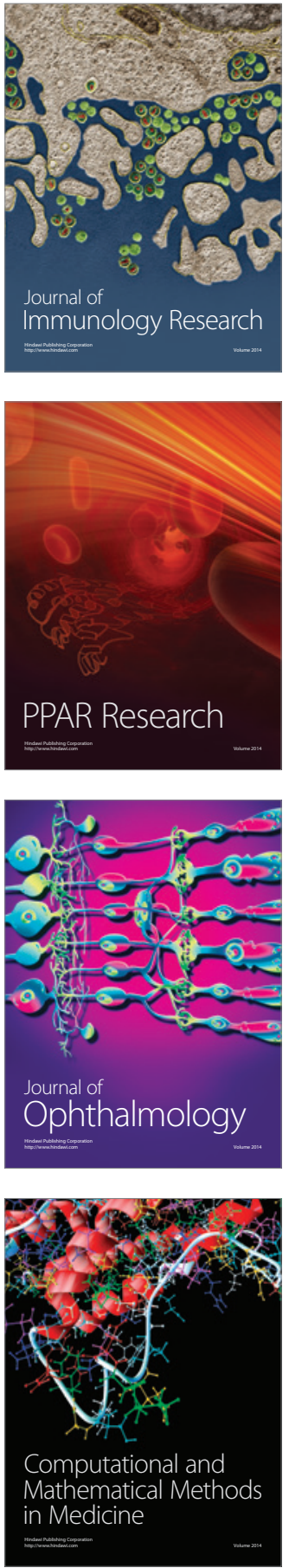

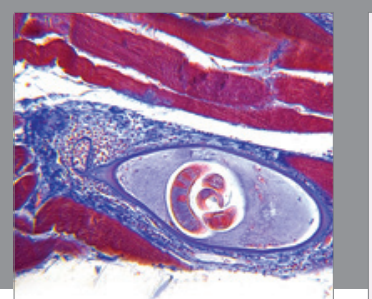

Gastroenterology Research and Practice
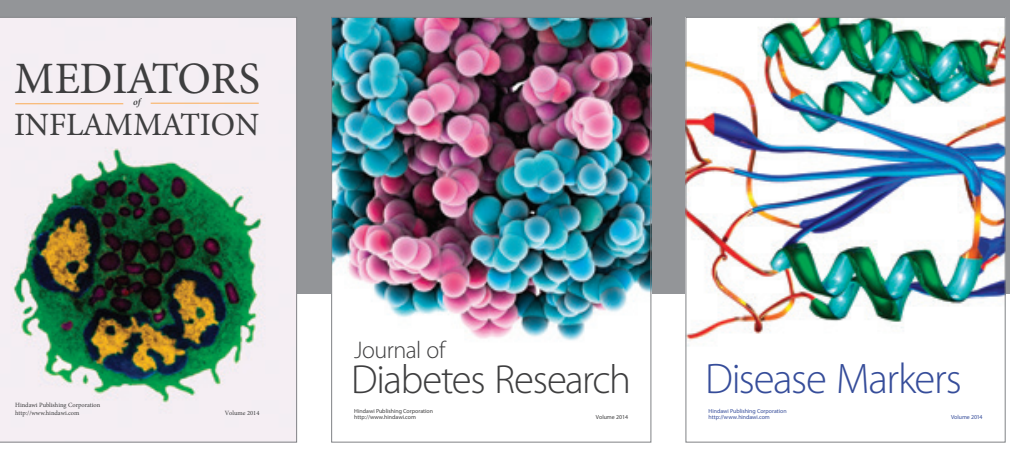

Disease Markers

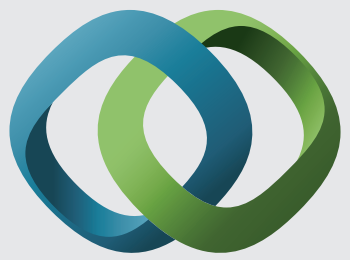

\section{Hindawi}

Submit your manuscripts at

https://www.hindawi.com
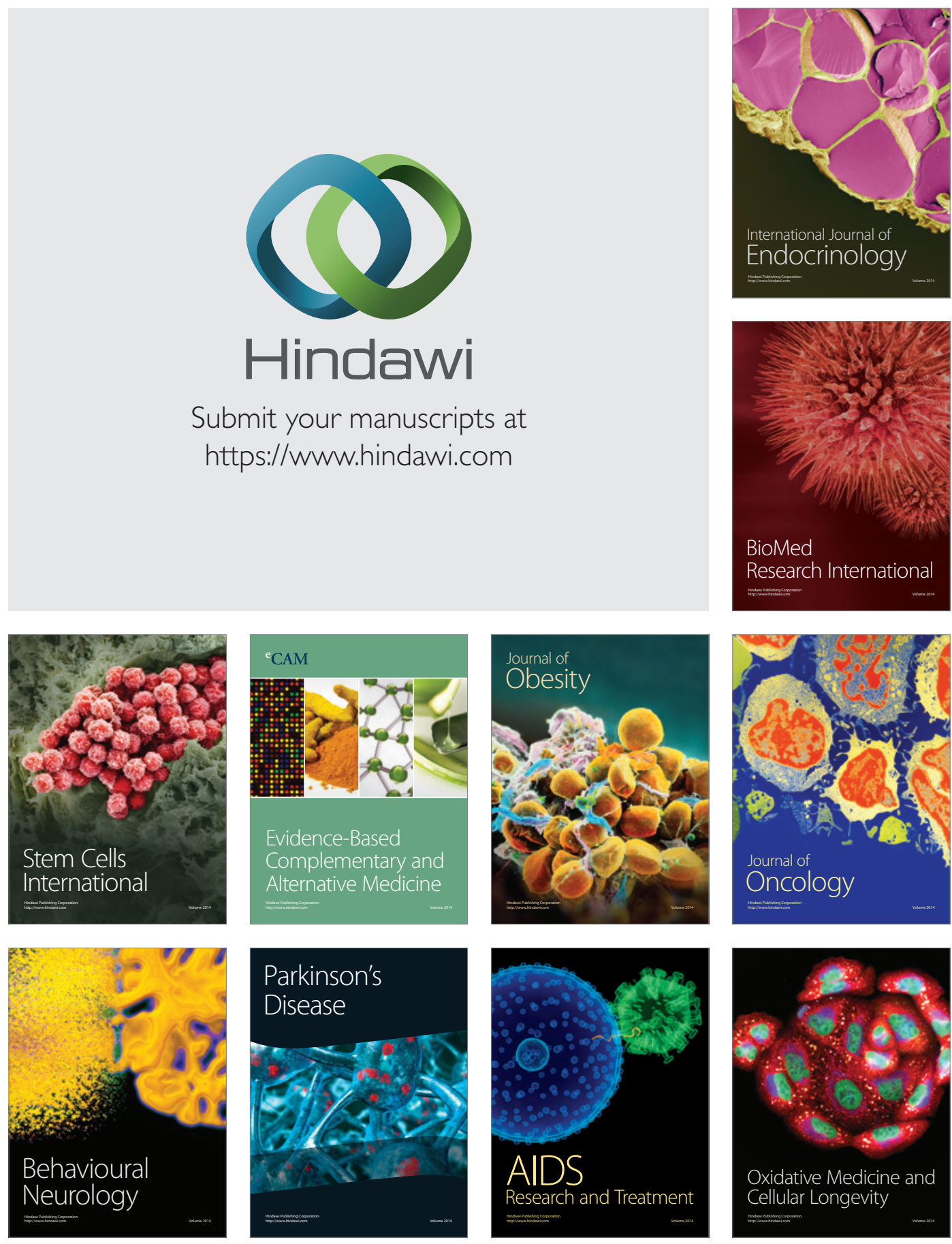